Archived version from NCDOCKS Institutional Repository http://libres.uncg.edu/ir/asu/

Alm, J., Jackson, B. R., \& McKee, M. (2009). Getting the word out: Enforcement information dissemination and compliance behavior. Journal Of Public Economics, 93(3/4), 392-402.

doi:10.1016/j.jpubeco.2008.10.007

\title{
Getting the word out: Enforcement information dissemination and compliance behavior
}

\author{
James Alm, Betty R. Jackson, Michael McKee
}

\begin{abstract}
The question for the tax authority is how individuals become aware of enforcement effort. To be an effective tool in reducing tax evasion taxpayers must be aware of the current audit and penalty regime. We use laboratory experiments to examine the compliance impact of types of information dissemination regarding audit frequency and results. The information includes "official" information disseminated by the tax authority, and "unofficial", or informal, communications among taxpayers. Our results indicate that the effect of the type of post-audit information is conditional on whether the taxpayer is well informed of the audit rate prior to filing. We find that the tax authority would be served by pre-announcing audit rates credibly and by emphasizing the previous period audit frequency in annual reporting of enforcement effort.
\end{abstract}

\section{Keywords}

Tax compliance, Tax audits, Social norms 


\section{Introduction}

Taxpayer audits are a central feature of the voluntary compliance mechanism in the personal income tax system of many countries, largely because more frequent audits are thought to reduce tax evasion. Audits are thought to have a direct deterrent effect on those individuals actually audited; perhaps of more importance, audits are also thought to have an indirect deterrent effect on individuals not actually audited. However, the magnitude of these deterrent effects depends critically on the taxpayer being informed of enforcement efforts. As Plumley (1996) notes, "[i]t is generally believed ... that many taxpayers would perceive increased auditing by the IRS [Internal Revenue Service] as an increase in their chances of being audited, and that they would improve their voluntary compliance as a result". Yet, theways by which taxpayers become informed about audit intensity and then respond to their assessments of enforcement efforts are "open questions" (Plumley, 1996). A valid assessment of the effectiveness of audits must incorporate taxpayers' awareness of the likelihood of audit.

Informational effects can arise through official announcements of audit occurrences and results, media reports, and taxpayer-to-taxpayer communication. The responses of taxpayers to levels of enforcement are difficult to measure and so are not known precisely. In effect, one must construct a natural or controlled experiment to obtain an estimate of taxpayer awareness of enforcement. Dubin et al. (1990), utilize naturally occurring field data by employing U.S. state-level reporting data for the years 1977 to 1986 to estimate the effects of differences in audit rates on reported income. Their estimates indicated that the decline in audit rates over this decade led to a significant decline in income tax collections, which would imply that the taxpayers somehow became aware of the lower risk associated with evasion. More recent work by Dubin (2007) gives a similar result. As with all studies based on field data, these studies suffer from not having direct measures of noncompliance (thus the use of reported income, not unreported income), from being forced to contend with various econometric issues (e.g., the endogeneity of audit selection arising from budget constraints facing tax authorities), and from the inability to control for all variables that might affect taxpayer reporting decisions (e.g., changes in the tax laws, taxpayer attitudes, economic conditions).

In a novel effort to test more directly the deterrent effects of making taxpayers aware of audits, Slemrod et al. (2001) worked with the State of Minnesota to conduct a controlled field experiment. They selected a stratified random sample of roughly 2000 Minnesota taxpayers, and these taxpayers were sent a letter by the Minnesota Department of Revenue in January 1994 that the tax returns they were about to file would be "closely examined". The intent of the experiment was to see whether informing individuals about an increase in the probability of audit prior to filing a tax return would in fact increase their compliance. Slemrod et al. (2001) found that low- and middle-income taxpayers responded as predicted, by increasing their reported levels of income; however, they also found the surprising and unexpected result that high-income taxpayers reduced their reported income, even with the threat that their return would be "closely examined", a threat clearly intended to convey higher probability of audit. 
However, their work did not have information on compliance but rather used reported income, an indirect measure of compliance because the taxpayers receiving the letters were not actually audited. Further, since there was only one information treatment in their field experiment, they were not able to compare compliance behavior across information programs nor were they able to ascertain any effects on compliance of taxpayer-to-taxpayer communication. The ways in which recipients of the "closely examined" letter interpreted this phrase are also uncertain.

Consequently, despite the many important insights from empirical studies using naturally occurring or experimental-based field data, there remains no systematic evidence on the impact on compliance of the ways in which audit information is disseminated to taxpayers or communicated by taxpayers. Tax agencies, such as the IRS, are largely ignorant of this most important aspect of increasing enforcement efforts. The typical economics-of-crime approach to tax evasion suggests that compliance can be increased through more enforcement, yet the key policy issue is how information regarding enforcement efforts is disseminated and subsequently affects compliance, and this issue remains unresolved.

We utilize a laboratory market setting to investigate the effects of information concerning enforcement and compliance behavior of others on the tax reporting behavior of individual taxpayers. While an understanding of how taxpayers form beliefs regarding enforcement efforts would be of interest in its own right, our focus here is on the interaction between information dissemination and compliance behavior. In our laboratory setting we are able to manipulate, as treatments, the information presented to the taxpayers and to offer taxpayers opportunities to communicate within their cohort the results of prior audits and past compliance. In the base case sessions, the participants receive no further information about audit results beyond their own audit experience. In a second treatment the same objective audit rates are in effect, and participants have additional information as they are told by the experimenter the actual number of audits conducted (and sometimes the fines collected) during a period. In a third treatment the participants are offered the opportunity to send a "message" to the other participants about their audit experience; subjects may also choose to send no message, and participants may send a message that is truthful or not. The experimental design therefore allows us to test hypotheses about the awareness of audit probabilities arising from two types of information dissemination regarding audit policies and results: "official" information disseminated by the "tax authority" (experiment software), and informal or "unofficial" communications among "taxpayers" (subjects). Further, the design allows us to estimate the direct and indirect effects of audits in ways that overcome some of the econometric issues arising with field data.

Since our design implements two extreme regimes of pre-filing information regarding audit probabilities we analyze the data for these regimes separately. Individual characteristics affect compliance rates about the same in each regime. However, the responses to official and unofficial information do vary across the regimes in ways that are consistent with arguments developed in the paper. Briefly, our results suggest that taxpayers will respond to wide ranging information sources that report the enforcement 
effort. These responses are more prominent when the taxpayers are not provided audit probabilities prior to making their filing decisions. Overall, our results yield an estimate of the indirect effect on compliance of 4.4 times the direct effect on compliance, an estimate that falls within the range of estimates from field data.

\section{Theoretical background}

The economic model of income tax evasion (Allingham and Sandmo, 1972) is based on the economics-of-crime approach pioneered by Becker (1968) and focuses on the income reporting behavior of taxpayers, ignoring other forms of evasion such as nonpayment, excessive reporting of deductions, and non-filing. In its simplest form, an individual is assumed to receive a fixed amount of income I, and must choose how much of this income to declare (to the tax authorities). The individual pays taxes at rate $t$ on every dollar $\mathrm{D}$ of income that is declared, while no taxes are paid on underreported income. However, the individual may be audited with a fixed, predetermined probability $\mathrm{p}$; if audited, then all underreported income is discovered, and the individual must pay a penalty at rate $f$ on each dollar of taxes that he or she underreported. The individual's income IC if caught underreporting equals $I C=I-t D-f[t(I-D)]$, while if underreporting is not caught income IN is IN=I-tD. The individual then chooses declared income to maximize the expected utility $E U(I)$ of the evasion gamble, or

$$
E U(I)=p U\left(I_{C}\right)+(1-p) U\left(I_{N}\right),
$$

where $E$ is the expectation operator and utility $U(I)$ is a function only of income. This optimization generates a standard first-order condition for an interior solution; given concavity of the utility function, the second-order condition will be satisfied. Comparative statics results are easily derived. It is straightforward to show that an increase in the probability of detection $p$ and in the penalty rate $f$ unambiguously increases declared income.

This standard model has been modified in a number of ways, partly in an attempt to generate predicted compliance rates that more closely fit actual compliance rates. Incorporating non-expected utility behavior (e.g., individuals exhibiting loss aversion or more extreme forms of risk aversion, such as rank dependent expected utility) yields predictions of compliance levels more consistent with observed behavior (Bernasconi, 1998). For example, for individuals described by rank dependent expected utility the basic maximization problem of Eq. (1) is modified, following Quiggin (1993), to obtain:

$$
E U(I)=g(p) U\left(I_{C}\right)+(1-g(p)) U\left(I_{N}\right),
$$

where $\mathrm{g}(\mathrm{N} 1)$ serves to overweight the probability of the "bad" outcome (detection and punishment) and to underweight the "good" outcome (successful evasion). Overweighting leads to higher compliance levels than those predicted under the standard expected utility problem for the same enforcement.

An alternative extension incorporates the notion of a "social norm" in compliance. Although difficult to define precisely, a social norm can be distinguished by the feature 
that it is process-oriented, unlike the outcome-orientation of individual rationality (Elster, 1989). A social norm represents a pattern of behavior that is judged in a similar way by others and that is sustained in part by social approval or disapproval. This suggests an individual will comply as long as he or she believes that compliance is the social norm; if noncompliance becomes pervasive, then the social norm of compliance disappears. Official and unofficial communications can clearly affect this social norm.

There are several ways in which a social norm can be introduced. Perhaps the simplest way is suggested by Kahneman and Tversky (1979), who incorporate what they term a "reference point" as a form of social norm in prospect theory. They assume that a loss in utility occurs if individuals do not achieve their reference point. The reference point may be achieved by reporting all income and paying all taxes; individuals who declare less than their full income and pay less than their full taxes will suffer a loss in utility. More formally, assume that each individual still maximizes $E U(I)$, defined as in Eq. (1) but where IN is reduced by the amount $\mathrm{Y}[\mathrm{t}(\mathrm{I}-\mathrm{D})]$. The individual now is assumed to suffer a (monetized) cognitive cost proportional to undisclosed taxes, and the coefficient $Y$ measures (as a fraction of income) how much the individual would pay to avoid the loss associated with each dollar of unreported taxes. If the noncompliance is detected (and punished), then the cognitive cost is assumed to be covered by paying the penalty. Clearly, $\mathrm{y}$ is likely to be sensitive to the social norm of tax compliance. The stronger is the social norm, the more deviant the behavior of a noncompliant individual becomes, and the more loss the individual feels. Of course, Eq. (2) can be similarly modified.

In all of these analyses it is assumed that taxpayers know the actual audit probability and penalties when making their compliance decisions. What is unavoidably and necessarily missing from the empirical work of Dubin et al. (1990), Dubin (2007), and others is a model of the manner by which information concerning the true audit probability and levied fines is communicated among the taxpayers and how changes in enforcement result in changed levels of compliance, perhaps through changes in perceived audit probabilities, through changes in overweighting, or through changes in social norms. The IRS may announce that it will raise or lower the audit rate, and we know from Slemrod et al. (2001) that this announcement may affect compliance. As emphasized earlier by Plumley (1996), an open empirical question is how a taxpayer forms an assessment of the probability of audit and, in particular, then responds to changes in this assessment.

The responses to information reporting current period audit results depend on whether official audit probabilities have been (credibly) pre-announced. When the audit probability has not been pre-announced, information reporting high audit activity will increase the subjective probability of an audit while information that reports low audit activity will lower this probability. In these (Series B) settings information reporting compliance/evasion behavior will be less likely to affect compliance behavior. When the audit probability is pre-announced (Series A), the effect of information reporting auditing activity will have less effect while information regarding compliance/evasion behavior will be more likely to affect compliance than in the Series B setting. 
We do not know individual taxpayer optimal compliance rates for a given enforcement regime since we do not elicit risk preferences. We do know that our aggregate compliance rate is less than one. Since the objective of the tax authority is to increase compliance and its policy basket includes enforcement information, our experimental investigations inform the agency of the direction of effects of information treatments.

\section{Experimental design}

The experimental design captures the essential features of the voluntary income reporting and tax assessment system used in many countries. Human participants in a controlled laboratory environment earn income through their performance in a task and decide how much of this income to report to a tax agency. Taxes are paid on reported income only. However, unreported income may be discovered via a random audit, and the participant must then pay the owed taxes plus a fine based on the unpaid taxes. This income earning, income reporting, audit, and penalty process is repeated for a given number of rounds each representing a tax period. At the completion of the experiment, all participants are paid in cash their laboratory market earnings converted to U.S. dollars.

The policy question investigated is: how does the transmission of information about enforcement efforts affect compliance behavior? The experimental design specifically addresses this question by introducing treatments that provide different forms of information regarding audit probabilities and results. Our experimental design follows the elements of much of the earlier research (e.g., Becker et al., 1987; Alm et al., 1992a,b), incorporating additional features to improve parallelism with taxpayers' decision making in the naturally occurring world.12 Participants earn income by performing a task (rather than receiving an endowment), disclose income, and face an audit process similar to that in the naturally occurring setting. The current experiments utilize tax language in the instructions and computer interface. The stakes are small, but the decision is simplified implying that the ratio of decision costs and rewards parallels the naturally occurring setting (Smith and Walker, 1993).

Participants are recruited from the pool of undergraduate students at a major public university. Upon arrival at the laboratory, the participants are assigned to a computer station. The lab server assigns participants to groups (consisting of six to eight persons depending on the total number of participants in the session). The participants do not know who is in their group, only the number in their group, and they know that there are at least two groups in the session. Having multiple groups in a session increases anonymity for the participants. Basic instructions are provided via hardcopy while the main instructions are provided via a series of screen images. After the practice rounds are completed, any final procedural questions are answered. Participants are not allowed to communicate with one another during the session except when allowed via the computer interface as a treatment. They are not told the exact duration of the experimental session, which is predetermined to last for 30 real rounds. Sessions take on average 90 min to complete. Participant earnings range from $\$ 19$ to $\$ 37$, depending upon task earnings, reporting behavior, and audit experience. 
Participants are told that payments will be made in private at the end of the session and that all responses are anonymous.

The earnings task requires the participants to sort the digits 1 through 9 into the correct ascending order from a randomized order presented in a 3 by 3 matrix. Participants do this by pointing the computer mouse and "clicking" on the numbers in the correct sequence. On their computer screen a 3 by 3 matrix with the digits in random order appears on the right side of the screen and as the numbers are "clicked" they appear in a 3 by 3 matrix on the left side of the screen. A counter on the screen shows the elapsed time from when the first number is "clicked" to the point when all nine have been ordered. The participant clicks the "Continue" button to transmit this time to the server. Actual income is determined by the relative speed of performance, with the fastest performer receiving the highest income and the slowest performer receiving the lowest income. Once all participants have completed the income task, they are informed via the computer of their income for the round and presented with a screen that resembles a tax form in which they may report their income. This screen informs the participants of the tax policy information in effect for the session.

Table 1 Experimental design and aggregate results

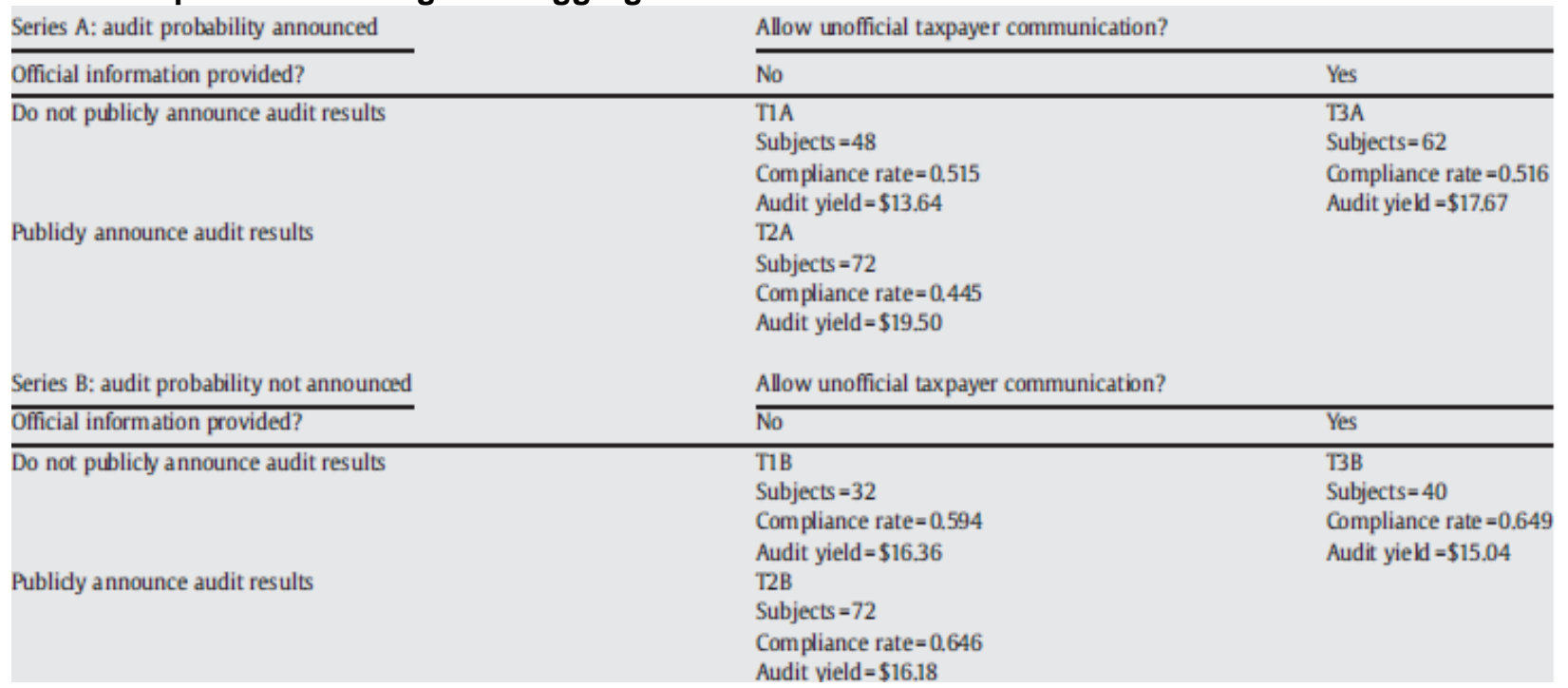

The experimental design consists of six treatments (Table 1). In all sessions the tax rate is set at 0.35 and the fine rate is set at $150 \%$. There is no public good financed by the tax payments. The currency used is called "lab dollars", and participants are told that all lab dollars earned during the session will be redeemed for cash at the end of the session at a fixed conversion rate of 90 lab dollars per 1 U.S. dollar. The probability of audit is set at one of the levels: $0.05,0.10,0.30$, and 0.40 . Each of these probabilities is applied for all of the treatments shown in Table 1. In all sessions participants are informed of the current tax rate and the penalty rate applied to non-disclosed income. All audits investigate only the current period disclosure. The experiment uses a between subjects design; each subject participates in only one treatment (session). The assignment of participants to treatments is completely randomized; all participants are drawn from the pool of potential subjects who had signed up for lab experiments. In 
each session, the audit probability is changed once (beginning in round 16) so that each participant faced two of the audit probabilities used in the experiment design for further randomization and in approximately half of the sessions the audit probability increased.

There are several ways in which "official" information regarding the audit activity of the tax authority could reach taxpayers and, potentially, affect compliance. The tax authority may or may not announce the audit probability (e.g., the fixed and predetermined audit rate); also, the tax authority may or may not announce the audit results (the number of audits actually conducted and/or the total fines actually collected from the audits). This "official" information is assumed to be treated as credible by the taxpayers.

Accordingly, we have partitioned our sessions into two primary groups to investigate the impact of such official information. In the first, denoted "Series A" in Table 1, the audit probability is announced to all subjects prior to the tax filing decision. In the second ("Series B" in Table 1), the audit probability is not announced. Thus, the Series A and B settings can be considered to represent the extremes in the level of prior audit probability information.

We investigate another "official" information mechanism by which reports of auditing results could be transmitted to the taxpayers. In the first treatment T1, in both Series A and $B$, participants are not provided with "official" information from the tax authority on the results of any audits actually conducted. In the second treatment T2, the actual number of audits conducted is reported at the end of each period; in some sessions in the T2 treatment the subjects are also told the aggregate fines collected via the audits.

Finally, we investigate the role of what we term an "unofficial" information mechanism. For this mechanism, denoted T3 (in both Series A and B), the participants are permitted to send one message (via the computer) each round to all persons in their group. The possible messages are reported in Table 2. This unofficial communication process works as follows. Before the next round begins, the participants receive a table of information on their computer screen that reports all the messages sent by the others in their group. The information is presented in a table presented to the subjects that shows the frequency of each message. Since the actual number of audits is not reported in this setting, there is no means by which the subjects can verify whether this information is truthful15, and indeed the experimental setting does not impose the requirement that the information be truthful.

Table 2 Allowed messages in Treatment 3

\begin{tabular}{lll} 
Message & Message content & Number of messages sent \\
\hline 1 & Do not send a message & 544 \\
2 & I was not audited & 681 \\
3 & I was audited & 281 \\
4 & I was not audited and did not report all my taxes & 549 \\
5 & I was not audited and reported all my taxes & 558 \\
6 & I was audited and did not report all my taxes & 253 \\
7 & I was audited and reported all my taxes & 194
\end{tabular}

At the end of the session, the participants complete a short questionnaire by reporting their age, gender, and whether they prepare and file their own taxes. 
The process of determining who is audited is generated by a computerized draw. In sessions in which the audit probability is announced, the participants are presented with an animated (computerized) representation of a bucket from which a draw is made. In this bucket there are 20 blue and white balls, with a white ball signifying no audit and a blue ball denoting an audit. Each taxpayer is audited independently. The balls "bounce" in this bucket and, after a random interval, a door opens and a ball exits the bucket through this door (blue for audit, white for no audit). When the audit probabilities are not announced, the bucket does not appear on the screen; the taxpayer simply receives a text message that reports whether he or she was audited or not. In these sessions, after the taxpayer reports income, there is a delay while the server performs a random process that is identical to that used by the virtual bingo cage and announces the audit result.

After the audit process is completed, the taxpayers are presented a new screen that provides the earnings and audit outcome summary for the round. Where taxpayer-totaxpayer communication is allowed (T3A and T3B), participants then choose to send one of the messages reported in Table 2. After all taxpayers have sent a message, they receive further feedback in the form of a table that reports the number of persons sending each of the messages. In the treatment for which audit result information is provided by the tax authority (T2A and $\mathrm{T} 2 \mathrm{~B}$ ), the taxpayers are provided a screen that reports the results of the audits for the individual's group. Thus, the groups in a given session will observe different end of round information concerning the audits conducted in their group. When provided, "official" information reports the number of audits conducted in the current round and, in a few sessions, the fines collected in the current round.

To summarize, in Series A sessions subjects are told the official audit probability, while in Series B they are not given this information. In T1 the subjects learn only their own audit experience, in T2 the subjects learn the official count of the number of persons in their group that are audited (and in some cases the aggregate fines), and in T3 the participants receive messages from others in their group that report audit results and compliance behavior of the persons in their group. Treatment T1B therefore represents the baseline setting of minimum official information, in which neither the audit probability nor the audit results are announced, so that subjects know only about their own audit experience. Treatment T2A represents the setting with maximum official information: both the audit probability and the audit results are announced. T1B also represents the treatment with minimum official and minimum unofficial information because the audit probability is not announced, the audit results are not announced, and subjects are not allowed to send messages. Treatments T2B and T1A are intermediate cases of official information; in T2B the audit results but not the audit probability are announced, while in T1A the audit probability but not the audit results are announced. Treatments T3A and T3B allow unofficial communication, with (T3A) and without (T3B) official audit probability information.

Our design constructs "groups" of individuals, by design, for the purposes of communicating the results from the audit process. These groups mimic naturally 
occurring cohorts in the sense that they have common interests by the design of the experiment (similar to the approach of Alm and McKee, 2004). The information communicated to the others may provide benefits in the same way that such communication would benefit associates in the naturally occurring setting. The total number of participants is 326 and the number of participants for each treatment is shown in Table 1.

\section{Compliance hypotheses}

The experimental design yields data allowing investigation of attributes of information that contribute to increased or reduced compliance. As in the naturally occurring world, individuals can obtain varying levels of information regarding the objective probability of an audit. The tax authority (experimenter) can announce the audit probability for the period, there may be less precise information based on prior periods, there may be discussion among taxpayers, or there may only be an individual's own audit experience.

As discussed in Section 2, the impact of official information on compliance depends in part on the underlying model of decision making under uncertainty of the taxpayer. Individuals with extreme forms of risk aversion, including those with rank dependent expected utility preferences, will focus on reports of the "bad" outcome (e.g., being audited), and official information reporting audit occurrences will lead to increases in subjective audit risk. Such individuals will react by increasing compliance whether the true audit probability has been announced or not. This reasoning yields:

H1. Official announcements of audit results (the number of individuals audited and/or the fines collected) in the previous period will, ceteris paribus, increase compliance.

If the data reject this hypothesis either it is the case that the individuals do not focus on the audits themselves or that the audit results are consistent with a lower probability than individual priors.

Taxpayers can engage in communication with friends and acquaintances concerning their experiences at the hands of the tax auditors, and such "unofficial" information will affect future compliance decisions. Here the issue is whether taxpayer communication concerning audit selection and audit outcomes leads to higher or lower compliance. If we continue to assume that individuals possess utility functions that overweight bad outcomes, communication reporting audits and audit results will work in the same direction as the official release of information. On the other hand, messages that suggest audits arise only rarely or are unable to detect evasion will reduce the perception that successful audits occur. Taken together these effects lead us to:

H2. Reports of low audit frequency in the previous period will lead to reduced compliance. Reports of high audit frequency will increase compliance, and this effect will increase as the number of audits increases.

An important additional aspect of our experimental design is that we are able to investigate some aspects of the effects of social norms on tax compliance. To the extent 
that paying taxes is viewed as a social contract, communications that others are complying will lead to higher compliance; conversely, communication that others cheat will lower compliance. Put differently, information (both official and unofficial) regarding taxpayer behavior will influence - either increasing or decreasing - the social norm of compliance:

H3. Reports that others are compliant with the tax rules will lead to higher compliance on the part of individuals receiving this information. Similarly, reports that others do not comply will lead to lower compliance.

The range of possible unofficial messages in Table 2 is quite large, but these messages may be usefully grouped for analysis. For example, there are two messages ( 5 and 7 ) that the individual complies with the tax law, while two messages (4 and 6) report evasion. Three messages report that one was audited $(3,5$, and 7$)$, and three report that one was not audited (2, 4, and 5). These classifications allow us to investigate the relative effects of taxpayer communication that may have either a positive or a negative effect on compliance.

The effect of past own audits on individual compliance behavior will vary by whether the audit probability is known prior to filing. The taxpayer may use the audit experience to update his or her probability of being audited in the future, and such updating can lead to lower or higher future compliance. If the individual feels he or she had underestimated (overestimated) the probability of an audit, then (assuming a Bayesian updating process) the response to a past audit will be to increase the estimated probability and thereby to increase (decrease) compliance in the future. Our design allows us to examine the effects of past audits on compliance.

\section{Experimental results}

Raw results are reported in Table 1, where Compliance Rate is defined as the tax reported divided by the tax owed, and Audit Yield reports the average penalty plus tax owed collected via audits in the given treatment; in each case these variables are calculated as a simple average across all subjects and rounds. Based on casual inspection, it appears that providing any end of period audit information increases compliance in the absence of a pre-announced audit probability. The compliance rate is higher in T2B and T3B than T1B. When the audit probability is pre-announced, the official announcement of audits lowers subsequent compliance, while taxpayer-totaxpayer communication does not change compliance behavior. However, a more complete understanding of the effects of the treatment variables requires econometric investigation of the data, which permits examination of interaction effects, learning, and differential impacts of information on compliance. There are two pre-filing information regimes in the experiment design (as seen in Table 1). In the one case (Series A) the taxpayers are informed of the exact audit probability prior to the filing decision, while in the other case (Series B) the taxpayers 
Table 3 Summary statistics

\begin{tabular}{|c|c|c|c|}
\hline Variable & Definition & $\begin{array}{l}\text { Series A: } \\
\text { mean (standard deviation) }\end{array}$ & $\begin{array}{l}\text { Series B: } \\
\text { mean (standard deviation) }\end{array}$ \\
\hline Declared income & Income reported to tax authority & $\begin{array}{c}38.69 \\
(36.77)\end{array}$ & $\begin{array}{r}51.700 \\
(35.49)\end{array}$ \\
\hline Compliance rate & Tax paid/tax owed & $\begin{array}{r}0.488 \\
(0.45)\end{array}$ & $\begin{array}{c}0.635 \\
(0.426)\end{array}$ \\
\hline Income & Income earned via the earning task (scaled in models) & $\begin{array}{r}80.219 \\
(12.13)\end{array}$ & $\begin{array}{r}81.667 \\
(11.67)\end{array}$ \\
\hline Wealth & Accumulated earnings to date (scaled in models) & $\begin{array}{l}965.483 \\
(574.39)\end{array}$ & $\begin{array}{r}918.210 \\
(540.59)\end{array}$ \\
\hline Audit probability & Probability of an audit in the current round & $\begin{array}{c}0.214 \\
(0.15)\end{array}$ & $\begin{array}{c}0.215 \\
(0.14)\end{array}$ \\
\hline Lag audited & $\begin{array}{l}\text { Dummy variable equal to } 1 \text { if the individual was audited } \\
\text { in the previous period and } 0 \text { otherwise }\end{array}$ & $\begin{array}{r}0.198 \\
(0.40)\end{array}$ & $\begin{array}{r}0.239 \\
(0.43)\end{array}$ \\
\hline $\begin{array}{l}\text { Official audit } \\
\text { results announced }\end{array}$ & $\begin{array}{l}\text { Dummy variable equal to } 1 \text { if taxpayers receive official information } \\
\text { regarding audit results from current round and } 0 \text { otherwise }\end{array}$ & $\begin{array}{r}0.395 \\
(0.49)\end{array}$ & $\begin{array}{c}0.500 \\
(0.500)\end{array}$ \\
\hline $\begin{array}{l}\text { Official number of } \\
\text { audits (lagged) }\end{array}$ & $\begin{array}{l}\text { Amount of total fines when such information is announced from } \\
\text { the previous round }\end{array}$ & $\begin{array}{c}0.648 \\
(1.27)\end{array}$ & $\begin{array}{l}0.879 \\
(1.33)\end{array}$ \\
\hline Unoffidal messages & $\begin{array}{l}\text { Dummy variable equal to } 1 \text { if any communication between taxpayers } \\
\text { is allowed via computer and } 0 \text { otherwise }\end{array}$ & $\begin{array}{r}0.341 \\
(0.47)\end{array}$ & $\begin{array}{r}0.278 \\
(0.45)\end{array}$ \\
\hline $\begin{array}{l}\text { Unoffidal message - subject } \\
\text { not audited(lagged) }\end{array}$ & $\begin{array}{l}\text { Number of taxpayers in group sending a message that included not } \\
\text { being audited (Messages 2, } 4 \text { and } 5 \text { - Table 2) }\end{array}$ & $\begin{array}{r}1.638 \\
(2.41)\end{array}$ & $\begin{array}{l}0.99 \\
(1.75)\end{array}$ \\
\hline $\begin{array}{l}\text { Unofficial message - subject } \\
\text { audited (lagged) }\end{array}$ & $\begin{array}{l}\text { Number of taxpayers in group sending a message that included being } \\
\text { audited (Messages 3,6 and } 7 \text { - Table 2) }\end{array}$ & $\begin{array}{c}0.589 \\
(1.16)\end{array}$ & $\begin{array}{l}0.507 \\
(1.03)\end{array}$ \\
\hline $\begin{array}{l}\text { Unoffidal message - subject } \\
\text { evaded (lagged) }\end{array}$ & $\begin{array}{l}\text { Number of taxpayers in group sending a message that included tax } \\
\text { evasion (Messages } 4 \text { and } 6 \text { - Table } 2 \text { ) }\end{array}$ & $\begin{array}{c}0.729 \\
(1.28)\end{array}$ & $\begin{array}{c}0.451 \\
(0.915)\end{array}$ \\
\hline $\begin{array}{l}\text { Unofficial message - subject } \\
\text { complied (lagged) }\end{array}$ & $\begin{array}{l}\text { Number of taxpayers in group sending a message that included tax } \\
\text { compliance (Messages } 5 \text { and } 7 \text { - Table } 2 \text { ) }\end{array}$ & $\begin{array}{c}0.669 \\
(1.19)\end{array}$ & $\begin{array}{r}0.421 \\
(0.87)\end{array}$ \\
\hline Prepared own tax return & $\begin{array}{l}\text { Dummy variable equal to } 1 \text { if the individual reports preparing and filing } \\
\text { own taxes in post-experiment survey and } 0 \text { otherwise }\end{array}$ & $\begin{array}{r}0.308 \\
(0.46)\end{array}$ & $\begin{array}{r}0.382 \\
(0.49)\end{array}$ \\
\hline Age & Taxpayer age as reported in post-experiment survey & $\begin{array}{l}20.20 \\
(3.18)\end{array}$ & $\begin{array}{l}20.04 \\
(2.80)\end{array}$ \\
\hline Male & $\begin{array}{l}\text { Dummy variable equal to } 1 \text { if taxpayer indicated gender as male in } \\
\text { post-experiment survey }\end{array}$ & $\begin{array}{r}0.500 \\
(0.50)\end{array}$ & $\begin{array}{l}0.569 \\
(0.49)\end{array}$ \\
\hline
\end{tabular}

have no information concerning the current audit probability. 20 The compliance effect of information from the previous period regarding audits will depend on the prior information regarding audit probability. Given the polar initial conditions, we have elected to examine the data for each separately as this allows us to focus on the information transmission from the cleaner starting point - no announcement of audit rates versus an explicit announcement. As expected, the response to post-audit information differs across audit rate announcement regimes and we are able to identify this in our data.

The experimental data constitute a panel as each subject makes one decision in a round (income to declare). The variables that are expected to affect this decision are the experimental treatments (e.g., the official information provided and the unofficial taxpayer-to-taxpayer communication), the results from previous rounds, the audit probability and certain subject characteristics. While we collect some subject characteristic data, and find that these systematically affect estimated compliance behavior, we acknowledge that we may be missing some unobservable effects. We employ a generalized least squares panel random effects estimator (see Wooldridge, 2002; Davidson and MacKinnon, 2004).

Theory suggests that the dependent variable, the individual Compliance Rate in each round, depends upon the individual's actual (or "true") earned Income in the round, Wealth (or accumulated earnings of the individual), the probability of audit (Audit 
Probability), individual characteristics, and variables representing the information and communication treatments. The information and communication variables are constructed from the experimental design as discussed below. Individual characteristics include a dummy variable for whether the individual has experience with preparing his or her own tax return (Prepared Own Tax Return), a dummy variable for gender (Male) to control for any systematic effects across subjects due to gender, and a variable (Age) to control for subject age.

The information and communication variables are of several types. "Official" information includes the announcement of audit results (Official Audit Results Announced), which may report the number of persons audited in the current period, the total or

Table 4 Estimation results for dependent variable Compliance Rate

\begin{tabular}{|c|c|c|c|c|}
\hline \multirow[t]{2}{*}{ Independent variables } & \multirow{2}{*}{$\frac{\text { Series A }}{\text { Model } 1}$} & \multirow{2}{*}{$\frac{\text { Series A }}{\text { Model } 2}$} & \multirow{2}{*}{$\frac{\text { Series B }}{\text { Model } 1}$} & \multirow{2}{*}{$\frac{\text { Series B }}{\text { Model } 2}$} \\
\hline & & & & \\
\hline$\overline{\text { Constant }}$ & $\begin{array}{l}0.558^{\text {*k*k }} \\
(8.94)\end{array}$ & $\begin{array}{l}0.549^{\text {*k*k }} \\
(9.24)\end{array}$ & $\begin{array}{l}0.551^{\text {*akk }} \\
(9.520)\end{array}$ & $\begin{array}{l}0.544^{* 0 *} \\
(10.03)\end{array}$ \\
\hline Income & $\begin{array}{l}-0,177^{* 0 * k} \\
(3.80)\end{array}$ & $\begin{array}{l}-0.168 \text { *** } \\
(3.59)\end{array}$ & $\begin{array}{l}-0.076^{*} \\
(1.66)\end{array}$ & $\begin{array}{l}-0.086^{*} \\
(1.88)\end{array}$ \\
\hline Wealth & $\begin{array}{l}-0.219^{* * * *} \\
(19.34)\end{array}$ & $\begin{array}{l}-0.218^{* * *} \\
(19.46)\end{array}$ & $\begin{array}{l}-0.181^{* * *} \\
(16.12)\end{array}$ & $\begin{array}{l}-0.187^{\text {*a* }} \\
(16.77)\end{array}$ \\
\hline Prepared own tax return & $\begin{array}{l}-0.031 \text {. } \\
(2.51)\end{array}$ & $\begin{array}{l}-0.031 \text { *ak } \\
(2.49)\end{array}$ & $\begin{array}{l}-0.060^{\text {*akk }} \\
(5.43)\end{array}$ & $\begin{array}{l}-0.060^{k 1 k} \\
(5.40)\end{array}$ \\
\hline Age & $\begin{array}{l}0.009^{* *} \\
(4.89)\end{array}$ & $\begin{array}{l}0.009^{* * 1 * k} \\
(4.89)\end{array}$ & $\begin{array}{l}0.021^{\text {*k*k }} \\
(11.71)\end{array}$ & $\begin{array}{l}0.022^{* * 1 *} \\
(12.50)\end{array}$ \\
\hline Male & $\begin{array}{l}-0.174^{* k * k} \\
(15.47)\end{array}$ & $\begin{array}{l}-0.174^{\text {*k*k }} \\
(15.47)\end{array}$ & $\begin{array}{l}-0.171^{\text {*k-k }} \\
(15.62)\end{array}$ & $\begin{array}{l}-0.174^{\text {*k*k }} \\
(16.06)\end{array}$ \\
\hline Audit probability & $\begin{array}{l}0.931^{\text {*k*k }} \\
(11.03)\end{array}$ & $\begin{array}{l}0.974^{* 1 * k} \\
(11.59)\end{array}$ & $\begin{array}{l}-0.061 \\
(0.78)\end{array}$ & $\begin{array}{l}-0.047 \\
(0.60)\end{array}$ \\
\hline Audit probability $\times$ round & $\begin{array}{l}-0.017^{7 * k} \\
(1.93)\end{array}$ & $\begin{array}{l}-0.019^{k * k} \\
(2.15)\end{array}$ & $\begin{array}{l}0.016^{* * *} \\
(1.95)\end{array}$ & $\begin{array}{l}0.018^{* * *} \\
(2.10)\end{array}$ \\
\hline Lag own audit & $\begin{array}{l}-0.009 \\
(0.47)\end{array}$ & $\begin{array}{l}-0.029 * \\
(1.82)\end{array}$ & $\begin{array}{l}-0.005 \\
(0.27)\end{array}$ & $\begin{array}{l}0.003 \\
(0.27)\end{array}$ \\
\hline Lag own audit ×official information provided & $\begin{array}{l}-0.043 \\
(1.48)\end{array}$ & & $\begin{array}{l}0.011 \\
(0.46)\end{array}$ & \\
\hline Unofficial message allowed & $\begin{array}{l}0.103 \\
(1.21)\end{array}$ & $\begin{array}{l}-0.011 \\
(0.72)\end{array}$ & $\begin{array}{l}0.280^{k-k *} \\
(4.40)\end{array}$ & $\begin{array}{l}0.113^{* * * *} \\
(7.81)\end{array}$ \\
\hline Official information provided & $\begin{array}{l}-0.082^{* *} \\
(2.51)\end{array}$ & $\begin{array}{l}-0.074^{* 10} \\
(5.23)\end{array}$ & $\begin{array}{l}0.128^{* 1 *} \\
(4.15)\end{array}$ & $\begin{array}{l}0.088^{* 0 * 4} \\
(6.52)\end{array}$ \\
\hline (Lag) Official total number audited reported & $\begin{array}{l}0.012^{* k *} \\
(2.04)\end{array}$ & & $\begin{array}{l}-0,026^{* * * k} \\
(4.83)\end{array}$ & \\
\hline (Lag) Unofficial message: subject not audited & $\begin{array}{l}-0.013 \\
(1.00)\end{array}$ & & $\begin{array}{l}-0.037^{* k 1 k} \\
(3.53)\end{array}$ & \\
\hline (Lag) Unofficial message: subject audited & $\begin{array}{l}0.017 \\
(1.29)\end{array}$ & & $\begin{array}{l}0.026^{* * *} \\
(2.27)\end{array}$ & \\
\hline (Lag) Unofficial message: subject evaded & $\begin{array}{l}-0.028^{k * * *} \\
(3.67)\end{array}$ & & $\begin{array}{l}-0.014 \\
(1.30)\end{array}$ & \\
\hline (Lag) Unofficial message: subject complied & $\begin{array}{l}0.027^{\text {*kak }} \\
(3.16)\end{array}$ & & $\begin{array}{l}0.023^{*} \\
(1.89)\end{array}$ & \\
\hline Round & $\begin{array}{l}0.008^{k * k} \\
(2.52)\end{array}$ & $\begin{array}{l}0.008^{* * *} \\
(3.34)\end{array}$ & $\begin{array}{l}-0.000 \\
(0.08)\end{array}$ & $\begin{array}{l}-0.001 \\
(0.27)\end{array}$ \\
\hline Round $\times$ official audit information & $\begin{array}{l}-0.001 \\
(0.07)\end{array}$ & & $\begin{array}{l}0.000 \\
(0.16)\end{array}$ & \\
\hline Round $\times$ unofficial audit information & $\begin{array}{l}-0.002 \\
(0.63)\end{array}$ & & $\begin{array}{l}-0.000 \\
(0.06)\end{array}$ & \\
\hline Panek/observations & $182 / 5278$ & $182 / 5278$ & $144 / 4176$ & $144 / 4176$ \\
\hline Wald & $1390.80^{* k-k}$ & $1340.36^{k * * *}$ & $856.68^{* 2 * k}$ & $809.52^{* * *}$ \\
\hline Log-likelihood & -2712.41 & -2732.45 & -1497.24 & -1510.19 \\
\hline
\end{tabular}

average fines, or some combination of these. The cleanest signal is the total number audited (Official Number of Audits) in the round since this only depends on enforcement effort while the fines collected information also contains some information about overall compliance behavior. This variable enters the model with a one period lag. The 
individual knows whether he or she was audited in all settings, and the individual lagged audit result (Lag Audited) is included. "Unofficial" communication among the subjects includes the possibility of sending any type of message (Unofficial Message Allowed), as well as the four different combinations of these messages (plus the possibility of sending no message at all, or Unofficial Message - Do Not Send Message). Definitions and summary statistics are reported in Table 3.22 In each audit regime, learning is captured through the use of the Round variable, and this is interacted with whether or not the subject receives official (Round $\times$ Official) or unofficial (Round $\times$ Unofficial) information regarding enforcement effort.

We report the results of two basic specifications in Table 4. The complete specification (Model 1) includes the set of interaction effects to capture the means by which the information concerning audits and compliance behavior affect individual compliance decisions. The simpler specification (Model 2) includes only the binary treatment variables for comparison. Both specifications include the basic set of explanatory variables.

As predicted, compliance is negatively correlated with income and wealth. Across all specifications and initial information settings, we find that compliance increases with subject age, is lower for males, and is negatively correlated with whether the individual reports preparing his or her own tax return.

Compliance is positively correlated with Audit Probability when this information is provided (Series A) but, as expected, has no significant effect when the rate is not known prior to the compliance decision. Interestingly, when the audit rate is preannounced the effect of the audit probability on compliance declines over time (Audit Probability $\times$ Round) but when the rate is not pre-announced (Series B), the coefficient on this variable is positive (at the 0.05 level). An individual's own audit immediate experience (Lag Own Audit) generally has no effect on compliance. This is true when the past audit experience was interacted with the provision of official information (Lag Own Audit× Official Information Provided). Absent public announcement of the audit probability all information would appear to increase compliance from the baseline. For Series B, the coefficient on both Official Information and Unofficial Messages are positive (at the 0.01 level). Interestingly, the provision of Official Information lowers compliance in the setting where the audit probability has been pre-announced (significant at the 0.01 level)

The effect of official information reporting the number of individuals audited in the previous round (Lag Official Number Audited Reported) poses an interesting issue. In the setting in which the audit rate is pre-announced, the coefficient is positive (significant at 0.05 level) which suggests that this information confirms a perception that audits are occurring and this leads to higher compliance. However, in the setting in which the audit probability is not pre-announced, the coefficient is negative (significant at 0.01 level) and this would imply that reports of audit activity lead individuals with less information regarding enforcement effort to reduce their compliance. This seems anomalous. Official information in general increases compliance but this specific 
information appears to reduce compliance. This seems a worthy topic for some further research.

Finally, the results for the Unofficial Information messages are particularly interesting. There is a clear difference across the audit rate announcement regimes. When the audit probability is announced the messages reporting audit outcomes are not significant but the messages reporting compliance behavior are significant (at the 0101 level) and the signs are consistent with a social norm explanation. The more frequent the messages that others comply, the higher the individual compliance rate and vice versa for messages reporting evasion. When the audit probability is not announced, the messages regarding compliance behavior are at best weakly significant. However the messages reporting audit outcomes are highly significant and consistent with the subjects utilizing the information to update their probability priors. Thus, we observe that the coefficient for the variable reporting audits is positive (significant at the 0.01 level) while for reporting not being audited is negative (also significant at the 0.01 level).

\section{Conclusions}

How do taxpayers become informed of enforcement efforts, and how do they respond to this information? We use experimental methods to examine the effects on compliance of different means by which taxpayers may learn about and communicate audit risk and compliance behavior. Our data permit us to estimate the compliance effects of information via both official and unofficial channels. The results suggest that the effect of some types of information is independent of the level of prior knowledge of enforcement effort (audit probability) but that some types of information are more consistently linked to higher compliance when the audit probability is initially unknown. Taken as a whole, our results suggest that the tax authority should support a policy of pre-announcing the audit rate and then reinforcing this with reports of the frequency of actual audits undertaken in the previous period. If it is determined that pre-announcing the audit probability is not credible, then the tax authority would be served by auditing a sufficiently high fraction of individuals so that taxpayer-to-taxpayer communications report the occurrence of audits sufficiently often. However, taxpayer-to-taxpayer communication will generally lower compliance unless audit frequencies are much higher than current levels.

Of further interest, our results indicate that the effect of audits is not limited to those actually audited. We estimate that the indirect effect of audits, calculated as the taxes collected from those not audited divided by the total audit yield, is 4.4 ; that is, total taxes collected are $440 \%$ greater than the revenues directly collected via the audit process itself. This ripple effect is comparable to estimates provided by Dubin et al. (1990) and Dubin (2007), all of which were generated from field data. Our experiments also provide some support for the effect of social norms (or social capital) in individual tax compliance decisions. When messages from other taxpayers report substantial levels of compliance among taxpayers, individuals are more likely to comply in subsequent rounds. Conversely, compliance declines when messages are consistent with widespread evasion. 
Although our experiments involve small numbers of persons and small stakes, they provide observations of behavior that are unavailable in the field. This information allows us to address some important behavioral questions concerning the responses of individuals to different types of information dissemination about audit information and audit results, none of which can be investigated using field data. We do not evaluate whether information communicated among taxpayers is or is not truthful, since taxpayers in our experimental setting (as in the naturally occurring world) have no means of determining the veracity of any communications. This important issue is left to future research.

\section{Acknowledgments}

We are grateful to Kim Bloomquist and John Deskins for the many helpful comments and discussions throughout this research. Earlier versions of this paper were presented at the 2004 IRS Research Conference, the 2004 Annual Meetings of the National Tax Association, McMaster University, Carleton University, and the 2006 ESA North American meetings in Tucson.We thank all session participants for their helpful comments, especially John Scholz and Arthur Snow. Michael Jones programmed the experiments. David Bruner, John Deskins, and Zach Richards provided very able assistance in running the experiments. An anonymous referee provided several comments that led to substantial improvements in both the empirical analysis and the exposition of the paper. Funding for this research was provided by the Internal Revenue Service (TIRNO-03-R-00027). All results and interpretations are those of the authors. 


\section{References}

Allingham, M., Sandmo, A., 1972. Income tax evasion: a theoretical analysis. Journal of Public Economics $1(4), 323-338$.

Alm, J., McKee, M., 2004. Tax compliance as a coordination game. Journal of Economic Behavior and Organization 54 (3), 297-312.

Alm, J., McKee, M., 2006. Audit certainty, audit productivity, and taxpayer compliance. National Tax Journal 59 (4), 801-816.

Alm, J., Jackson, B.R., McKee, M., 1992a. Institutional uncertainty and taxpayer compliance. The American Economic Review 82 (4), 1018-1026.

Alm, J., McClelland, G.H., Schulze, W.D., 1992b. Why do people pay taxes? Journal of Public Economics $48(1), 21-38$.

Andreoni, J., Erard, B., Feinstein, J., 1998. Tax compliance. Journal of Economic Literature 36 (2), $818-$ 860.

Becker, G.S., 1968. Crime and punishment - an economic approach. The Journal of Political Economy 76 (2), 169-217.

Becker,W., Buchner, H.-J., Sleeking, S.,1987. The impact of public transfer expenditures on tax evasion: an experimental approach. Journal of Public Economics 34 (2), 243-252.

Bernasconi, M., 1998. Tax evasion and orders of risk aversion. Journal of Public Economics 67 (2), $123-$ 134.

Coleman, J., 1988. Social capital in the creation of human capital. American Journal of Sociology 94 (Supplement), S95-S120.

Cowell, F., 1990. Cheating the Government: The Economics of Evasion. The MIT Press, Cambridge, MA.

Cummings, R., Martinez-Vazquez, J., McKee, M., 2006. An experimental investigation of mixed modes of tax evasion. Public Finance Review 34 (6), 663-686.

Dasgupta, P., Serageldin, I. (Eds.), 2000. Social Capital: A Multi-faced Perspective. The World Bank, Washington, D.C.

Davidson, R., MacKinnon, J.G., 2004. Econometric Theory and Methods. Oxford University Press, New York, NY.

Dubin, J.A., 2007. Criminal investigation enforcement activities and taxpayer noncompliance. Public Finance Review 35 (4), 500-529.

Dubin, J.A., Graetz, M.J., Wilde, L.L., 1990. The effect of audit rates on the federal individual income tax, 1977-1986. National Tax Journal 43 (4), 395-409. 
Elster, J., 1989. The Cement of Society. Cambridge University Press, Cambridge, MA.

Erard, B., Feinstein, J.S., 1994. The role of moral sentiments and audit perceptions in tax compliance. Public Finance/Finances Publiques 49 (Supplement), 70-89.

Frey, B.S., 1997. Not Just for the Money: An Economic Theory of Personal Motivation. Edward Elgar Publishers, Cheltenham, UK.

Gerxhani, K., Schram, A., 2006. Tax evasion and the source of income. Journal of Economic Psychology 27 (3), 402-422.

Gordon, J.P.F., 1989. Individual morality and reputation costs as deterrents to tax evasion. European Economic Review 33 (4), 797-805.

Internal Revenue Service, 1996. Federal Tax Compliance Research: Individual Income Tax Gap Estimates for 1985, 1988 and 1992. IRS Publication 1415 (Rev. 4-96). Washington, D.C.

Kahneman, D., Tversky, A., 1979. Prospect theory: an analysis of decision under risk. Econometrica 47 (2), 263-291.

Myles, G.D., Naylor, R.A., 1996. A model of tax evasion with group conformity and social customs. European Journal of Political Economy 12 (1), 49-66.

Plott, C.R., 1987. Dimensions of parallelism: some policy applications of experimental methods. In: Roth, A.E. (Ed.), Laboratory Experimentation in Economics: Six Points of View. Cambridge University Press, New York, NY, pp. 193-229.

Plumley, A.H., 1996. The determinants of individual income tax compliance: Estimating the impacts of tax policy, enforcement, and IRS responsiveness. Internal Revenue Service Publication 1916 (Rev. 1196). Washington, D.C.

Pommerehne,W.W., Hart, A., Frey, B.S.,1994. Tax morale, tax evasion, and the choice of tax policy instruments in different political systems. Public Finance/Finances Publiques 49 (Supplement), 52-69.

Quiggin, J., 1993. Generalized Expected Utility Theory: The Rank Dependent Model. Kluwer Academic Publishers, Boston, MA.

Reinganum, J., Wilde, L.L., 1988. A note on enforcement uncertainty and taxpayer compliance. Quarterly Journal of Economics 103 (4), 793-798.

Slemrod, J., Yitzhaki, S., 2002. Tax avoidance, evasion, and administration. In: Auerbach, A.J., Feldstein, M. (Eds.), Handbook of Public Economics. Elsevier, Amsterdam, pp. 1423-1470.

Slemrod, J., Blumenthal, M., Christian, C., 2001. Taxpayer response to an increased probability of an audit: evidence from a controlled experiment in Minnesota. Journal of Public Economics 79 (3), 455483.

Smith, V.L., 1982. Microeconomic systems as an experimental science. The American Economic Review 72 (4), 923-955. 
Smith, V.L., Walker, J., 1993. Monetary rewards and decision cost in experimental economics. Economic Inquiry 31 (2), 245-261.

U.S. Department of the Treasury Inspector General for Tax Administration (TIGTA), 2002. Management Advisory Report: The Internal Revenue Service's Response to the Falling Level of Income Tax Examinations and Its Potential Impact on Voluntary Compliance, Reference Number: 2002-30-092. Washington, D.C.

Webley, P., Robben, H., Elffers, H., Hessing, D., 1991. Tax Evasion: An Experimental Approach. Cambridge University Press, Cambridge, UK.

Wooldridge, J.M., 2002. Econometric Analysis of Cross Section and Panel Data. The MIT Press, Cambridge, MA. 